\title{
Потенціал оздоровчо-рекреаційних технологій при організації сімейного дозвілля
}

\author{
Дмитро Мальцев, Інна Хрипко
}

Національний університет фізичного виховання і спорту України, Київ, Україна

Анотація. У статті розглянуто потенціал оздоровчо-рекреаційної рухової активності під час організації сімейного дозвілля. Мета. Вивчити доцільність та перспективність використання оздоровчо-рекреаційних технологій в організації активного сімейного дозвілля. Методи. Теоретичний аналіз даних спеціальної науково-методичної літератури, узагальнення, систематизація, абстрагування, синтез, аналогія, індукція, дедукція, логічний метод, соціологічні методи дослідження. Результати. Досліджено алгоритм організації оздоровчорекреаційної діяльності: визначення наявності оздоровчо-рекреаційних потреб у населення в контексті організації вільного часу; виявлення фрізкультурно-рекреаційних уподобань населення, тих форм і видів активного відпочинку, які є цікавими як дітям і дорослим окремо, так і для обох вікових груп; визначення обізнаності дітей та членів їхніх сімей у сфері способів організації активного відпочинку і діяльність з їх фрізкультурно-рекреаційної освіти розробка системи залучення дітей та їхніх батьків до участі у фізкультурно-рекреаційних заходах і реалізація цієї системи; планування майбутньої фрізкультурно-рекреаційної діяльності на основі попереднього аналізу відповідних потреб та інтересів учасників, розробка відповідних програм, сценаріїв тощо; визначення критеріїв ефективності фізкультурнорекреаційної діяльності; забезпечення діяльності матеріальними, фінансовими, інформаційними, технологічними і кадровими ресурсами; контроль і координація діяльності. Ключові слова: сімейне дозвілля, оздоровчо-рекреаційна рухова активність, технології.

\section{Dmytro Maltsev, Inna Khrypko}

\section{THE POTENTIAL OF HEALTH-RELATED AND RECREATIONAL TECHNOLOGIES IN THE ORGANIZATION OF FAMILY LEISURE}

Abstract. The potential of health-related and recreational motor activity during the organization of family leisure is considered in the article. Objective. To study the expediency and prospects of using health-related and recreational technologies in the organization of active family leisure. Methods. Theoretical analysis of data of special scientific and methodical literature, generalization, systematization, abstraction, synthesis, analogy, induction, deduction, logical method, sociological research methods. Results. The algorithm of the organization of healthrelated and recreational activity is investigated: definition of existence of health-related and recreational needs of the population in the context of the organization of free time; identification of physical culture and recreational preferences of the population, those forms and types of active recreation that are interesting for both children and adults separately, and for both age groups; determining the awareness of children and their families in the field of ways to organize active recreation and activities for their physical education and recreation; development of a system for involving children and their parents in participation in physical culture and recreational activities and implementation of this system; planning of future physical culture and recreational activities on the basis of preliminary analysis of relevant needs and interests of participants, development of appropriate programs, scenarios, etc .; determination of criteria for the effectiveness of physical culture and recreational activities; providing activities with material, financial, informational, technological and human resources; control and coordination of activities. Keywords: family leisure, health-related-recreational motor activity, technologies.
Вступ. Інтенсивність процесів глобалізації, обумовлена експансією інформаційно-комунікативних технологій в усі сфрери суспільного життя, призводить до зростання значення сорери дозвілля і рекреації, де людина має можливість не тільки відновлювати втрачені життєві сили, а й реалізувати свій творчий потенціал на шляху до самореалізації та самовдосконалення [16].

Питання організації сімейного дозвілля є актуальним у сучасному світі, оскільки сім'я становить унікальну основу суспільства, що володіє провідною роллю в процесі формування особистості. Проблемі активного сімейного дозвілля останнім часом приділяється чимало уваги, що знаходить відображення в сучасних соціальнокультурних, психолого-педагогічних дослідженнях [8]. Активне дозвілля трактується науковцями як вид діяльності, який добровільно обирається і здійснюється людиною у вільний час та має відновлювальний і оздоровчий ефрект, що включає соціально виправдані види занять [4, 17].

Питання наукового обґрунтування застосування різних засобів рухової активності та оцінки їх рекреаційного потенціалу розглянуто у дослідженнях багатьох науковців [1-7, 22, 31]. Технології проектування оздоровчорекреаційної діяльності різних груп населення знайшли своє практичне застосування в процесі фізичного виховання молодших школярів [7]; практиці роботи літніх оздоровчих таборів з дітьми середнього шкільного віку [10]; рекреаційної діяльності молоді $[18,30]$; рекреаційної діяльності осіб зрілого віку [2, 4, 6]. Раціональна організація сімейного дозвілля була предметом дослідження як вітчизняних, так і зарубіжних науковців $[1,21-23,31]$.

Дослідниками наголошується на необхідності реалізації різноманітних програм, спрямованих на подолання в Україні сучасного соціального виклику - низького рівня залучення насе- 
лення до оздоровчо-рекреаційної рухової активності як обов'язкової умови та генеруючої частини здорового способу життя [22]. В той самий час недостатньо обґрунтованим є використання технологій оздоровчорекреаційної діяльності в організації активного сімейного дозвілля, що обумовлює актуальність подальших досліджень у цьому напрямі.

Дослідження виконано відповідно до плану НДР НУФВСУ на 2021-2025 рр. за темою «Теоретичні та технологічні засади оздоровчорекреаційної рухової активності та здорового способу життя різних груп населення» (номер держреєстрації 0121U107534).

Мета дослідження - вивчити можливості використання технологій 03доровчо-рекреаційної рухової активності в організації активного сімейного дозвілля.

Методи дослідження: теоретичний аналіз даних спеціальної науковометодичної літератури, узагальнення, систематизація, абстрагування, синтез, аналогія, індукція, дедукція, логічний метод, соціологічні методи дослідження.

Результати дослідження та їх обговорення. У своєму дослідженні І. М. Єрошенков [12] дає таке визначення сімейного дозвілля: «... колективна діяльність, зміст і форми проведення якої залежать від рівня культури, освіти, місця проживання, доходів, національних традицій, віку членів сім'ї, їх індивідуальних схильностей і інтересів». Він виділяє такі його основні характеристики: сімейне дозвілля виконує специфічну роль, спрямовану на підтримання сім'ї як цілісної системи, колективу; перешкоджає проникненню в неї таких ворожих руйнівних сил, як алкоголь, нудьга, взаємне психологічне пересичення і відчуження; чинить розвиваючий вплив на всіх її членів: підвищує їх освітній, загальнокультурний рівень; згуртовує спільністю інтересів, переживань; $€$ дієвим засобом сімейного виховання: діти вчаться берегти час, любити природу, освоюють культуру сприйняття мистецтва, накопичують досвід спілкування, гостро усвідомлюють спільність сім'ї [12].
І. О. Щепетковою [28] визначено особливості дозвіллєвої діяльності: дійсний мотив, тобто потреба особистості в самому процесі цієї діяльності; мета і зміст дозвіллєвої діяльності обираються людиною залежно від їі менталітету (морального розвитку, культурного рівня, традицій) і можливостей (в тому числі фрінансових, сімейних); дозвіллєва діяльність може мати соціально корисний або соціально нейтральний характер, бути замкнутою в системі вузькогрупових цінностей і набувати асоціального чи навіть аморального характеру; дозвіллєву діяльність можна представити у вигляді пасивної (перегляд телепередач, прийом гостей, застілля), активної (прогулянки, відвідування театрів) і цілеспрямованої (спорт, полювання, подорожі) діяльності; циклічність дозвіллєвої діяльності; територіальне поширення дозвіллєвої діяльності обумовлюється, а точніше обмежується, багатьма фракторами, наприклад, часом, який відводиться на її реалізацію.

Рекреаційний потенціал розглядається у більшості досліджень як організація рекреаційної діяльності на певній території з урахуванням соціально-економічних, культурно-історичних і природних чинників. Рекреація має великий діапазон видів свого прояву відповідно до вікових особливостей, інтересів, фрізичних здібностей, інтелектуального рівня, смаків людини. Результат рекреаційної діяльності не має для людини істотного значення, самоцінністю володіє процес задоволення від здійснення рекреаційної діяльності.

Як зазначає С. В. Лавренцова, реалізація виховного потенціалу сімейного дозвілля може бути забезпечена на основі системи соціальнопедагогічного впливу, спрямованого на фрормування культури сімейного дозвілля як засобу духовно-інтелектуального наповнення вільного часу членів сім'ї, залучення їх до процесу безперервної освіти, спільної аматорської творчості та активних форм відпочинку; цілеспрямованого відбору форм діяльності, що сприяють створенню сприятливої соціально-психологічної атмоссрери в сім'ї; включення сім'ї в єдиний соціокультурний простір як цілісного суб'єкта соціально-культурної творчості, педагогічна ефективність якої залежить від спільних зусиль усіх ії суб'єктів [19].

Особливе місце в системі організації сімейного дозвілля займають рекреаційні технології, що сприяють фізичному і духовному відновленню людини, максимальному розвитку ініціативи, самостійності, що знімають фрізичне, психічне та інтелектуальне напруження, стимулюють соціальну активність і створюють оптимальні умови для творчого самовираження особистості. Все це дозволяє розглядати рекреаційні технології як засіб формування здорового сімейного дозвілля і культури побуту сучасної сім'ї [20].

Суть рекреаційних технологій полягає в організації дозвілля, спрямованого на зміцнення духовних і фрізичних сил, відновлення психічного здоров'я, розвиток і реалізацію творчого потенціалу особистості [11].

Дослідження Н. Пангелової, А. Сем'янчука [21] присвячене вивченню особливостей сімейного туризму, який має свої особливості, перш за все в тому, що оздоровлення і виховання органічно поєднуються із залученням дітей до систематичних занять туризмом, фрізкультурою, спортом. Сім'я виступає як важлива сфрера різнобічного розвитку особистості, iї матеріальних і духовних інтересів, активного використання вільного часу. У країнах зі сталим розвитком суспільство виявляє велику турботу про сім'ю і дітей. На це спрямовані подальший розвиток служби побуту, системи громадського харчування, створення широкої мережі дитячих та оздоровчих закладів, у тому числі і туристсько-рекреаційних. Сьогодні очевидними є виховні і моральні переваги сімейного туризму перед роздільним відпочинком дітей і батьків. Перш за все, він сприяє розвитку в сім'ях дружніх, партнерських відносин, формування у дітей працьовитості, самостійності, допитливості, зміцненню авторитету батьків. Під час спільних поїздок, подорожей розширюється світогляд дітей. 
За даними Д. І. Цвєткової, 0. В. Машкової [27], сімейний туризм вирішує такі завдання: сприяє згуртованості сім'ї і встановленню емоційного контакту, взаєморозуміння, співробітництва між батьками і дітьми, корекції дитячо-батьківських взаємин, реалізації сімейних цінностей; реалізує потребу у відпочинку і фрізичній активності (особливо це стосується спортивних видів сімейного туризму), орієнтує на здоровий активний спосіб життя; сприяє активній соціалізації дітей. Багато видів сімейного туризму $€$ командними, спільна робота, співпраця, взаємодія у команді створюють природні умови для набуття соціального досвіду у дітей.

Підкреслюючи соціальну значущість різних видів туризму, Г. В. Талалаєва [24] виділяє ряд найважливіших функцій: зміцнення стабільності суспільства, консолідації сімейних відносин, формування картини світу і світогляду підростаючого покоління, забезпечення спадкоємності поколінь за способом життя і сценаріями групової поведінки. На думку автора, соціальні види туризму (до яких належить сімейний туризм) характеризуються не тільки високим напруженням міжособистісного спілкування, а й сприяють розвитку комунікації між поколіннями на побутовому рівні. Крім того, є швидкісним каналом передачі інформації потомству про належні і найбільш ефективні способи соціальної адаптації та стратегії толерантної поведінки, що дозволяють одночасно і синхронно формувати корисний життєвий досвід у двох-трьох і більше поколінь людей.

Проблема здоров'я особистості, формування здорового способу життя зосереджує в собі небезпечні виклики розвитку цивілізації, відповіді на які не можуть бути знайдені без зміни системи суспільних відносин і самої людини. Однією зі сфер життєдіяльності, де найбільш цілісно та якісно можуть вирішуватися завдання збереження здоров'я населення, є дозвілля. Саме тут може бути забезпечена активізація соціальних механізмів охорони здоров'я і пробудження особистісної ініціативи індивіда в самозбереженні на основі вибору спо- собу життя і різноманітних форм дозвілля [20].

Дозвілля, володіючи поліфункціональною різноманітністю, створюе широкий соціально-культурний простір для прояву творчої активност людини відповідно до їі вікових особливостей, інтересів, фрізичних можливостей та індивідуальних переваг. Організація відпочинку та розваг повинна мати розвиваючу спрямованість і бути націленою на підвищення культурного рівня життя особистості.

Специфіка організації сімейного дозвілля засобами оздоровчо-рекреаційних технологій визначається побудовою діяльності на добровільній основі, вибором соціально прийнятних рекреаційних видів діяльності, що сприяють розвитку індивіда і суспільства, а також об'єктивною потребою людського організму у відновленні свого психофрізичного балансу.

Під рекреативними технологія ми, по-перше, розуміють організацію рекреативної, ігрової, розважальної, фрізкультурно-оздоровчої діяльності. По-друге, це орієнтація на діяльність, спрямовану на підвищення культури побуту, на активне використання новітніх досягнень біології, фрізіології, психології, медицини [20].

Розрізняють кілька рівнів рекреативної діяльності, що різняться ступенем соціальної значущості, інтелектуальним і емоційним залученням, фізичною і духовною активністю особистості.

Перший рівень - пасивна рекреація - передбачає просте розслаблення, відпочинок від трудового дня, зняття емоційного напруження.

Другий рівень - активний - спрямований на витрату фрізичних і інтелектуальних сил, вольових зусиль, забезпечення емоційної і фрізично розрядки. Цей рівень включає різноманітні розважальні заходи - ігри танці, свята тощо.

Третій рівень рекреації пов'язаний зі значною активізацією духовних інтересів, переваг і можливостей людини. Саме він спонукає людину до розширення духовного світу й оволодіння культурними потребами.

Четвертий рівень рекреації орієнтований на виробництво певного виду культурних цінностей, розвиток творчості. Саме він дозволяє людині вдосконалювати різні сторони особистості і задовольняти різноманітні запити й інтереси у сфері вільного часу [9].

Як зазначає Ж. В. Муравйова [20], суть організації сімейного дозвілля засобами оздоровчо-рекреаційних технологій, які являють собою цілеспрямовано організований педагогічний процес здійснення діяльності у вільний час відповідно до рекреаційних потреб кожного члена сім'ї, результатом якого $є$ відновлення фізичного і психічного балансу людини.

Серед усього розмаїття підходів до рекреаційних технологій слід виділити такі групи [13]:

Перша група - рекреаційні технології, орієнтовані на перехід до створення довготривалих «наскрізних» оздоровчих програм, які передбачають послідовну участь населення в різноманітних оздоровчих заходах, дозвіллєвих заняттях. Вони включають використання в оздоровчій роботі засобів оздоровчого фрітнесу; реалізацію специфічних можливостей музично-медитативних і театральнооздоровчих програм, використання розмовної психотерапії, бібліотерапії, психогімнастики.

Другу групу становлять технології організації відпочинку та розваг. До цього типу технологій відносять використання та відродження традицій народної культури; відновлення старих і виникнення нових народних свят, обрядів і ритуалів; збагачення конкурсних, ігрових, художньо-видовищних, дозвіллєвих програм; індивідуальний, груповий, сімейний туризм тощо.

Свої інтереси і потреби сім'я може задовольнити вдома або в установах культурно-дозвіллєвого типу. За даним критерієм сімейне дозвілля можна розділити на домашнє та дозвілля з сім'єю поза домом. До домашнього дозвілля відносять аматорські заняття (квітникарство, колекціонування, догляд за домашніми тваринами, спільні заняття художньою і технічною творчістю, малювання тощо); спільне звернення до аудіовізуальної інфрормації (перегляд телепередач); домашні спектаклі (організація театралізацій та театральної діяльності, постановка 
композицій, ігрових програм, малоформатних вистав тощо).

Сімейне дозвілля за межами дому включає оздоровчий і спортивний сімейний відпочинок (естафети, масові забіги, пляжні турніри, фрітнесклуби, спортивні ігри, відвідування лазні); рекреативне сімейне дозвілля поза домом, наприклад, сімейний туризм; спільне відвідування театрів, музеїв, кінотеатрів, концертів та інших культурно-видовищних заходів; участь у масових святах і видовищних заходах; організація сімейних свят і ритуально-обрядових дійств.

Ученим [20] визначено такі соціально-культурні умови, які дозволяють організувати сімейне дозвілля засобами оздоровчо-рекреаційних технологій:

- виявлення та врахування факторів, котрі сприяють оптимізації процесу організації сімейного дозвілля;

- задоволення різноманітних рекреаційних потреб членів сім'ї з урахуванням вікових та індивідуальноособистісних особливостей;

- використання різних видів рекреаційної діяльності, що дозволяють виховувати культуру розумних обмежень, пропагувати цінності, підтримувати сімейні відносини;

- добровільність під час вибору виду занять і ступеня активності в процесі використання рекреативних технологій;

- здійснення цільового впливу на особу при їі активному залученні в рекреаційно-оздоровчу діяльність за рахунок зміни одного виду зайнятості, на інший;

- здійснення діяльності на основі дозвіллєвої програми, що передбачає залучення у видовищні, ігрові, фрізкультурно-оздоровчі та інші види дозвільних форм.

Серед рекреаційно-оздоровчих технологій значне місце займає велика за масштабами ігрова діяльність [6]. Ігрова діяльність володіє значними педагогічними та організаційнометодичними перевагами. Вона дозволяє істотно скоротити час на накопичення необхідної інформації, набуття тих чи інших умінь і навичок; сприяє імітації різних видів соціальної діяльності, розширює сферу контак- ту особистості з різними соціальними групами, організаціями і рухами, ознайомлення 3 багатьма жанрами мистецтва і літератури. Інтенсифікуючи саморефрлексію особистості, гра є дієвим інструментом поглиблення демократичності спілкування, співробітництва, соціального діалогу [29].

Технологія рекреаційно-оздоровчої діяльності орієнтована на оздоровлення способу життя людей і організацію ігрової, розважальної та фізкультурно-оздоровчої діяльності. Сьогодні основна увага працівників установ соціально-культурної ссрери спрямована на активне використання новітніх досягнень педагогіки, біології, фрізіології, психології та медицини, спрямованих на створення різноманітних культурно-дозвіллєвих програм і впровадження таких форм роботи, які сприяють відновленню емоційної рівноваги людей; можливості участі населення у відродженні народних свят; акцентують увагу на вільному творчому пошуку в гуртках і студіях, аматорських об'єднаннях і клубах за інтересами, майстернях і творчих лабораторіях [15].У процесі розробки більшості рекреаційних проєктів, орієнтованих на формування і розвиток культури дозвілля, основна увага фрахівців зосереджена на впровадженні в практику масового і спеціалізованого дозвілля новітніх технологій у галузі соціально-культурної діяльності. Тому особливе місце в рекреаційних технологіях займають анімаційні соціально-культурні технології, які знайшли широке застосування в організації дозвільної діяльності сімейних парків розваг. Організація сімейної дозвіллєвої діяльності в умовах сімейного парку розваг будується на таких принципах: спільної діяльності, зростання інтересу, рекреації і пізнання, компенсації, соціальної віддачі. Для ефрективної реалізації програми, спрямованої на формування і розвиток культури сімейного дозвілля, необхідні такі педагогічні умови: залучення дітей і батьків до дозвіллєвої діяльності; формування досвіду організації сімейної дозвіллєвої діяльності; здійснення програмного забезпечення організації сімейної дозвіллєвої діяльності на основі принципів ді- агностичної спрямованості, змістовної діяльності, психологічної підтримки [25].

На думку учених [14], для визначення змісту оздоровчо-рекреаційної діяльності необхідно спиратися на відповідні переваги, інтереси і потреби населення. Ефективність організованої фрізкультурно-рекреаційної діяльності визначається за показниками, пов'язаними із сутю та функціями фрізичної рекреації, а також з конкретними поставленими завданнями.

Виходячи з ознак, аспектів і видів фрізичної рекреації, було виділено такі завдання, пов'язані з організацією активного сімейного відпочинку: організація оздоровчо-рекреаційної діяльності (створення відповідних організаційних структур, фрірм з виробництва фрізкультурно-рекреаційних послуг); управління оздоровчо-рекреаційною діяльністю (організація, планування, забезпечення ресурсами, контроль і координація діяльності); надання фрізкультурно-рекреаційних послуг (як інструктора з виду спорту, організатора масових фрізкультурно-спортивних заходів та туристичних зльотів тощо); пропаганда фрізичної рекреації (рекламна діяльність у ссрері дозвілля населення) [26].

Організація оздоровчо-рекреаційної діяльності та управління нею передбачає послідовне вирішення таких завдань:

1) визначення наявності оздоровчо-рекреаційних потреб у населення (в нашому випадку - у дітей і їхніх батьків) у контексті організації вільного часу;

2) виявлення фрізкультурно-рекреаційних уподобань населення, тих форм і видів активного відпочинку, які $€$ цікавими як дітям і дорослим окремо, так і для обох вікових груп;

3) визначення обізнаності дітей та членів їхніх сімей про способи організації активного відпочинку і діяльність з їх фрізкультурно-рекреаційної освіти;

4) розробка системи залучення дітей та їхніх батьків до участі в фрізкультурно-рекреаційних заходах (пропаганда фрізичної рекреації, популяризація активного відпочинку тощо) і реалізація цієї системи;

5) планування майбутньої фрізкультурно-рекреаційної діяльності на осно- 
ві попереднього аналізу відповідних потреб та інтересів учасників, розробка відповідних програм, сценаріїв тощо;

6) визначення критеріїв ефективності фрізкультурно-рекреаційної діяльності (показників, які свідчать про позитивний вплив активного відпочинку на дітей і їхніх батьків);

7) забезпечення діяльності матеріальними, фрінансовими, інформаційними, технологічними і кадровими ресурсами; контроль і координація діяльності [14].

Висновки. Досліджено доцільність та перспективність використання оздоровчо-реркеаційних технологій в організації активного сімейного дозвілля. Визначено алгоритм організації оздоровчо-рекреаційної діяльності сімейного дозвілля. На вибір тих або інших занять у вільний час впливають соціальні моменти: вік, стать, сімейно-родинні відносини, мода, реклама, соціальний статус. Серед видів дозвіллєвої діяльності найбільш поширеними є: свята, заняття мистецтвом, мандрівки, ігрова діяльність, масові видовища, організована рухова активність. Результати дослідження свідчать про наявність стійкої потреби в культивуванні й підтриманні сімейних зв'язків через систему оздоровчо-рекреаційних заходів.

Перспективи подальших досліджень полягають в обґрунтуванні та розробці програми занять з використанням засобів оздоровчо-рекреаційної рухової активності для організації сімейного дозвілля.

Конфлікт інтересів. Автори заявляють, що відсутній будь-який конфрлікт інтересів.

\section{ЛІТЕРАТУРА}

1. Андрєєва 0. Особливості фрізично рекреації різних груп населення. Теорія і методика фізичного виховання та спорту. 2007;2:10 13.

2. Андрєєва 0. Чинники, що детермінують рекреаційну активність осіб зрілого віку. Слобожанський науково-спортивний вісник 2008;2(46):31-4.

3. Андрєєва 0. Концептуальні та прикладн аспекти технологізації проектувальної діяльності в сфері фізичної рекреації. Теорія і методика фрізичного виховання і спорту. 2013:1:35-40.

4. Андрєєва О. Розробка та впровадження технології проектування активної рекреаційної діяльності різних груп населення. Спортивний вісник Придніпров'я. 2015;1:4-9.

5. Андрєєва ОВ. Історичні, теоретикометодологічні засади рекреаційної діяльност різних груп населення. Слобожанський нау ково-спортивний вісник. 2015;2(46):19-22.

6. Андрєєва 0, Пацалюк К. Соціальнопсихологічні чинники, що детермінують рекреаційно-оздоровчу активність осіб різного віку. Теорія і методика фізичного виховання спорту. 2014;3(106):25-31.

7. Андрєєва 0, Чернявський М. Проблеми та перспективи впровадження рекреаційно оздоровчих занять в загальноосвітніх школах Теорія і методика фрізичного виховання і спорту. 2005;4:34-6.

8. Ариарский МА, Киселева ОИ, Медведь ЭИ, Новикова ИА, Новаторов ВЕ, Стрельцов ЮА, Вентцель КН. Семейный досуг как средство укрепления межличностных отношений в семье. Среднее профессиональное обра зование. 2018;10:55-9.

9. Белянский РГ. Рекреативные техноло гии как средство формирования навыков межкультурного общения студенческой молодежи. Вестник ТГУ. 2011:5:195-9

10. Гакман А, Андрєєва О. Руховий режим дітей у літньому оздоровчому таборі. Теорія і методика фрізичного виховання і спорту. 2011;4:35-41.

11. Ганьшина ГВ. Формирование здорового образа жизни молодежи средствами рекреативных технологий. [Автореферат]. Тамбов. 2005. 22 c.

12. Ерошенков ИН. Культурно-досуговая деятельность в современных условиях. Москва: НГИК. 1994. 32 с.

13. Киселева ТГ, Красильников ЮД. Сфера досуга в системе социальной защиты со временной семьи. Актуальные проблемь социально-культурной деятельности. Москва 1995. С. 48-55

14. Коблев ЯК, Хашканок АК. Организация активного отдыха населения по месту жительства средствами фризической рекреации. Уче ные записки университета Лесгафта. 2010;6:64

15. Ковалева КГ, Григорьева ЕИ. Роль рекреативно-оздоровительных технологий организации семейного досуга. Актуальные проблемы формирования творческой лично сти в условиях единого культурного пространства региона. Материалы IV заочной Всерос. науч.-практ. конф. с международным участием (Омск, 30 апреля 2014 г.). 273-9.

16. Кравцова ОА. Рекреационный досуг как предмет научного анализа. Вестник ЧГА КИ. 2013. №3 (35). URL: https://cyberleninka. ru/article/n/rekreatsionnyy-dosug-kak predmet-nauchnogo-analiza (дата обращения 08.06.2019)

17. Круцевич ТЮ, Андрєєва ОВ. Теоретичні основи дослідження фізичної рекреаці як наукова проблема. Спортивний вісник Придніпров'я. 2013;1:5-13

18. Круцевич Т, Андрєєва 0, Благій О. Рекреативні заняття як чинник формування дозвільної культури. Спортивний вісник Придніпров'я. 2008:1:3-7.

19. Лаврецова СВ. Социально-культурная деятельность как средство оптимизации семейного досуга [диссертация]. Санкт-Петербург. 2007. $230 \mathrm{c}$

20. Муравьева ЖВ. Социально-культурные условия организации семейного досуга средствами рекреативно-оздоровительных техноло гий. Вестник ТГУ. 2009;3:88-91.
21. Пангелова H, Сем'янчук А. Зарубіжний досвід організації сімейного відпочинку 3 дітьми у рекреаційно-туристичних комплексах. Теорія і методика фрізичного виховання і спорту. 2014;4:78-80.

22. Пасічняк Л, Дутчак М. Особливості залучення різних груп населення до активного відпочинку в умовах міського парку. Спортивна наука України. 2015;5(69):21-6.

23. Петрова IB. Дозвілля в зарубіжних країнах. 2008. 408 с.

24. Талалаева ГВ. Разработка инновационных технологий в ссрере социального менеджмента. Успехи современного естествознания. 2007;12:511-2

25. Теребенина И. Рекреационные технологии как фактор развития культуры досуга семьи на примере семейного парка развлечений «Планета смайлс» TPK «Куба» г. Челябинска. В: Материалы 44-45 научной студенческой конференции; 2013 Апрель 9; Челябинск; 2013. C. $227-230$.

26. Хашханок АК. Организация физкультурно-активного семейного отдыха населения средствами физической рекреации [Автореферат]. Майкоп: Адыгейский государственный университет. 2011. 29 с

27. Цвєткова ДІ, Машкова ОВ. Особливості організації сімейного відпочинку 3 дітьми дошкільного віку в Україні. Науковий вісник Херсонського державного університету. 2017;6:187-192

28. Щепеткова ИО. Досуг как научная категория: разнообразие подходов к изучению. Дискуссия. 2015. №6 (58). URL: https:// cyberleninka.ru/article/n/dosug-kak-nauchnayakategoriya-raznoobrazie-podhodov-k-izucheniyu

29. Ярошенко НН. Социально-культурная анимация: учебное пособие. Москва; 2004. C. 108

30. Andrieieva 0, Hakman A. Health status and morbidity of children 11-14 years of age during school. Journal of Physical Education and Sport, 2018;18(2):1231-6. DOI:10.7752/jpes.2018.s2183

31. Kashuba V, Andreeva 0 . The trends in recreational activity of different groups of ukrainians. . Reasearch yearbook. Studies in physical education and sport. Warzawa : Medsportpress. 2006; (12):145-7.

\section{LITERATURE}

1. Andreieva 0 . Peculiarities of physical rehabilitation of different population groups. Teoriia i metodyka fizvykhovannia i sportu. 2007;2:10-13.

2. Andreieva 0 . Factors determining recreation activity of adult persons. Slobozhanskyi naukovo-sport. visnyk. 2008;2(46):31-4

3. Andreieva 0._Conceptual and applied aspects of technologicalization of design activities in the field of physical recreation. Teoriia i metodyka fizvykhovannia i sportu. 2013;1:35-40.

4. Andreieva 0. Development and implementation of technology for designing active recreational activities of different groups of the population. Sportyvnyi visnyk Prydniprovia. 2015;1:4-9.

5. Andreieva 0. Historical, theoretico-methodological bases of recreation activity of different population groups. Slobozhanskyi naukovosport. visnyk. 2015;2(46):19-22.

6. Andreieva 0, Patsaliuk K. Socio-psychological factors determining the recreation and health-related activity of different age persons. Teoriia i metodyka fizvykhovannia i sportu. 2014;3(106):25-31. 
7. Andreieva 0, Cherniavskyi M. Issues and prospects of introducing recreational and healthrelated classes in general schools. Teoriia i metodyka fizvykhovannia i sportu. 2005;4:34-6.

8. Ariarsky MA, Kiseleva OI, Medved EI Novikova IA, Novatorov VE. Family leisure as a means of strengthening interpersonal relationships in the family. Sredneye professionalnoye jbrazovaniye. 2018;10:55-9.

9. Belyavsky RG. Recreative technologies as means of forming the skill of intercultural cooperation of student youth. Vestnik TGU. 2011;5:195-9

10. Hakman A, Andreieva 0. Children motor regime at summer camp. Teoriia i metodyka fizvyk hovannia i sportu. 2011;4:35-41.

11. Ganshina GV. Formation of youth healthy way of life by means of recreative technologies. [Author's abstract]. Tambov. 2005. 22 p.

12. Yeroshenkov IN. Cultural and leisure activity in contemporary conditions. Moscow: NGIK. 1994. 32 p.

13. Kiseleva TG, Krasilnikov YD. Leisure sphere in the system of modern family socia protection. Aktualnyye voprosy sotsio-kulturnoy deyatelnosti. Moscow. 1995. P. 48-55.

14. Koblev YK, Khashkanok AK. Organization of population active rest at places of residence by physical recreation means. Uchenyye zapiski universiteta imeni P. Lesgafta. 2010;6:64.

15. Kovaleva KG, Grigoryeva El. The role of recreational and health-related technologies in the organization of family leisure. Actual problems of the formation of a creative personality in a single cultural space of the region. Materialy IV Vseros. nauch.-prakt. konferentsiyi (Omsk, 30 April 2014). 273-9.

16. Kravtsova OA. Recreational leisure as the subject of scientific analysis. Vestnik CHGAKU. 2013. N3 (35). URL: https://cyberleninka ru/article/n/rekreatsionnyy-dosug-kak-predmet-nauchnogo-analiza (дата обращения: 08.06 2019).

17. Krutsevych T, Andreieva 0. Theoretical bases of studying physical recreation as scientific problem. Sportyvnyi visnyk Prydniprovia. 2013;1:5-13.
18. Krutsevych T, Andreieva 0, Blahii 0 . Recreative sessions as a factor of leisure culture formation. Sportyvnyi visnyk Prydniprovia. 2008 $1: 3-7$.

19. Lavretsova SV. Sociocultural activity as a means of family leisure optimization [dissertation] St. Petersburg. 2007. 230 p.

20. Muravyeva ZV. Sociocultural conditions of leisure organization through recreationa and health-related technologies. Vestnik TGU 2009;3:88-91.

21. Panhelova N, Semianchuk A. Foreign experience of organizing family rest in recreationa and touristic complexes. Teoriia i metodyka fizvykhovannia i sportu. 2014;4:78-80.

22. Pasichniak L, Dutchak M.Features of involvement of various groups of the population in active rest in the conditions of city park. Sportyvna nauka Ukrainy. 2015;5(69):21-6.

23. Petrova IV. Leisure in foreign countries 2008. 408 p.

24. Talalayeva GV. Innovation technology development in social management sphere. Uspekh sovremennogo yestestvoznaniya. 2007:12:511-2.

25. Terebenina I. Recreational technologies as a factor in the development of family leisure culture on the example of the family amusement park «Planet Smiles» TRK «Cuba» in Chelyabinsk. In: Materialy 44-45 nauchnoy studencheskoy kon- ferentsiyi; 2013 April 9; Chelyabinsk; 2013. P. 227 230.

26. Khashkhanok AK. Organization of physical-active family recreation of the population by means of physical recreation [Abstract]. Maykop: Adygeysky universitet. 2011. 29 p.

27. Tsvietkova DI, Mashkova OV. Features of leisure organization with preschool children in Ukraine. Naukovyi visnyk Khersonskoho universytetu. 2017;6:187-192.

28. Shchepetkova I0. Leisure as a scientific category: diversity of approaches to studying. Dis cussion. 2015. N6 (58). URL: https://cyberleninka. ru/article/n/dosug-kak-nauchnaya-kategoriyaraznoobrazie-podhodov-k-izucheniyu

29. Yaroshenko NN. Sociocultural animation: teaching guide. Moscow; 2004. P. 108.

30. Andrieieva 0, Hakman A. Health status and morbidity of children 11-14 years of age during school. Journal of Physical Education and Sport, 2018;18(2):1231-6. DOI:10.7752/jpes.2018.s2183

31. Kashuba V, Andreeva 0 . The trends in recreational activity of different groups of ukrainians. Reasearch yearbook. Studies in physical education and sport. Warzawa: Medsportpress. 2006; (12):145-7.

Надійшла 27.01.2021

\section{ІНФОРМАЦІЯ ПРО АВТОРІВ}

Мальцев Дмитро Костянтинович https://orcid.org/0000-0003-2127-3385, maltsev1994@ukr.net Хрипко Інна Василівна https://orcid.org/0000-0001-9969-5954, inna.khrypko@gmail.com

Національний університет фізичного виховання і спорту України 03150, Київ, вул. Фізкультури, 1

\section{INFORMATION ABOUT THE AUTHORS}

Maltsev Dmytro https://orcid.org/0000-0003-2127-3385, maltsev1994@ukr.net Khrypko Inna https://orcid.org/0000-0001-9969-5954, inna.khrypko@gmail.com National University of Ukraine on Physical Education and Sport 03150, Kyiv, Fizkul'tury str., 1 